\title{
Pengaruh Pra-perlakuan Paraquat Terhadap Kandungan Asam Askorbat Pada Tembakau (Nicotiana tabacum L.) var. MKY yang Dicekam Kekeringan
}

\author{
Muhammad Ichsan Al Farisy, Nurul Jadid \\ Departemen Biologi, Fakultas Ilmu Alam, Institut Teknologi Sepuluh Nopember (ITS) \\ e-mail: ichsanfaris66@gmail.com
}

\begin{abstract}
Abstrak - Kekeringan merupakan faktor utama yang membatasi pertumbuhan dan perkembangan tanaman serta berpengaruh terhadap produktivitas tanaman di seluruh dunia, utamanya di daerah tropis. Seperti halnya tanaman lain, tembakau juga mengembangkan mekanisme pertahanan terhadap cekaman kekeringan. Salah satu bentuk pertahanan tersebut yaitu tanaman melakuan mekanisme produksi antioksidan berupa asam askorbat. Penelitian ini bertujuan untuk mengetahui pengaruh paraquat (PQ) terhadap kandungan asam askorbat pada tembakau (Nicotiana tabacum L.) var. MKY yang dicekam kekeringan. Cekaman kekeringan dilakukan dengan cara melakukan penghentian pemberian air pada tanaman, serta digunakan PQ dengan konsentrasi $0.0005,0.001,0.0025$, dan $0.005 \%$. Parameter yang diukur adalah kandungan asam askorbat (AsA). Pemberian pra-perlakuan menggunakan paraquat dengan konsentrasi tersebut terbukti mampu meningkatkan kandungan asam askorbat. Paraquat dengan konsentrasi $0.001 \%$ dinilai merupakan konsentrasi yang paling optimal sebagai second messenger untuk meningkatkan respon N. tabacum dibawah cekaman kekeringan.
\end{abstract}

Kata kunci-Antioksidan, Paraquat, ROS, Second messenger, N. tabacum var. MKY

\section{PENDAHULUAN}

$\mathrm{C}$ EKAMAN lingkungan merupakan salah satu faktor eksternal yang dapat mempengaruhi pertumbuhan dan perkembangan tanaman [1]. Seperti halnya tanaman lain, produktivitas tanaman tembakau (Nicotiana tabacum L.) juga dipengaruhi oleh cekaman biotik dan abiotik. Faktor biotik meliputi serangan serangga, jamur dan mikrobia [2]. Sedangkan faktor cekaman abiotik meliputi kekeringan, suhu ekstrim, cekaman genangan, salinitas [3]. Diantara faktor abiotik tersebut, kekeringan merupakan faktor utama yang membatasi pertumbuhan dan perkembangan tanaman serta berpengaruh terhadap produktivitas tanaman di seluruh dunia, utamanya di daerah tropis [4].

Tembakau (N. tabacum L.) merupakan salah satu spesies dalam famili Solanaceae yang bernilai ekonomi tinggi (Rachmat et al., 2010). Tanaman tersebut merupakan tanaman non-pangan asli Amerika yang banyak dibudidayakan di hampir seluruh dunia [5]. Sejauh ini, daun tembakau diproses secara komersial sebagai bahan utama rokok dan cerutu [5]. Namun demikian, tembakau juga memiliki potensi untuk dikembangkan dalam industri kosmetik [6], bioenergy [7], biopestisida dan industri farmasi [8]. Selain itu, tanaman tersebut juga digunakan sebagai salah satu sistem model yang paling penting dalam pengembangan bioteknologi tanaman [9].

Di Indonesia terdapat banyak varietas tembakau yang telah dibudidayakan oleh petani. Beberapa varietas tersebut antara lain adalah Prancak 95, Marakot, Jepon Mawar, dan MKY. Masing-masing varietas tersebut memiliki karakteristik yang khas, baik karakter morfologi, fisiologi dan fitokimia [10]. Seperti halnya tanaman yang lain, tembakau juga memiliki mekanisme respon terhadap cekaman kekeringan.

Respon tersebut meliputi respon morfo-anatomi, fisiologi, molekuler dan biokimia [11]. Beberapa penelitian menunjukkan bahwa cekaman kekeringan dapat menghambat pertumbuhan akar [12], daun, batang [13]dan menginduksi penutupan stomata [14]. Selain itu [15] juga menyebutkan bahwa cekaman kekeringan berdampak pada menurunnya laju fotosintesis. Menurut penelitian yang dilakukan oleh [16], cekaman kekeringan juga berdampak pada perubahan ekspresi dari beberapa gen responsif terhadap cekaman kekeringan, diantaranya $N t A B A 2$, NtERD10B dan NtLTPI pada tiga varietas (Marakot, Jepon Mawar dan MKY), varietas MKY memiliki respon yang paling baik diantara ketiga varietas yang lain terhadap cekaman kekeringan.

Selain itu, salah satu bentuk umum respon tanaman terhadap cekaman kekeringan adalah diproduksinya ROS (Reactive Oxygen Species) dalam jumlah berlebih (Nxele, 2017). ROS yang terbentuk dapat menyebabkan deformasi membran sel sebagai akibat stres oksidatif pada membran lipid dan apparatus fotosintesis, merusak biomolekul lain seperti protein dan DNA hingga menyebabkan mutasi [17]. Beberapa contoh jenis ROS yang sangat reaktif adalah singlet oksigen $(, \mathrm{O} 2)$, hydrogen peroksida $(\mathrm{H} 2 \mathrm{O} 2)$, superoksida $\left(\mathrm{O}^{-}\right)$dan radikal hidroksil (,OH). Selain memberi dampak negatif, pada konsentrasi yang rendah, ROS juga berfungsi sebagai second 
messenger dalam sistem transduksi sinyal respon tanaman terhadap cekaman lingkungan [17].

Penelitian yang dilakukan oleh [18] membuktikan bahwa pra perlakuan menggunakan Paraquat (PQ) mampu meningkatkan enzim antioksidan dan melindungi sel-sel dari kerusakan oleh ROS pada tanaman mentimun (Cucumis sativus) dibawah cekaman kekeringan. Pra perlakuan tersebut dapat digunakan sebagai alternatif dalam meningkatkan ketahanan tanaman terhadap cekaman kekeringan . PQ adalah herbisida yang memiliki komponen aktif berupa metil viologen (MV; 1,1'-dimetil-4,4'-bipyridinium diklorida), memberi efek phytotoxic pada tanaman dengan mentransfer elektron dari fotosistem I ke molekul oksigen, mengakibatkan akumulasi radikal superoksida di kloroplas [19]. Hingga saat ini, penelitian tentang pengaruh PQ terhadap kandungan senyawa antioksidan pada tanaman tembakau varietas yang banyak dikembangkan di Indonesia masih jarang dilakukan. Oleh karena itu, penelitian ini bertujuan untuk mengetahui pengaruh pemberian $\mathrm{PQ}$ terhadap kandungan senyawa antioksidan berupa asam askorbat pada tanaman tembakau (Nicotiana tabacum L.) Var.MKY yang tercekam kekeringan.

Peneitian ini bertujuan untuk mengetahui pengaruh PQ terhadap kandungan asam askorbat pada tembakau (Nicotiana tabacum L.) var. MKY yang dicekam kekeringan.

\section{METODOLOGI}

\section{A. Pembibitan}

Biji Tembakau (Nicotiana tabacum L.) Var.MKY direndam didalam air selama 24 jam, benih kemudian disebar diatas nampan yang telah berisi media tanah kompos, pupuk NPK dan cocopeat dengan perbandingan 2:1:1 secara homogen. Setelah itu disemprot dengan fungisida dengan merk dithane untuk menghindari tumbuhnya jamur parasit. Kemudian dilakukan penyiraman sebanyak 1 kali sehari hingga tembakau memiliki 3-4 daun.

\section{B. Perlakuan sebelum pemberian cekaman}

Bibit yang telah tumbuh dan memiliki 3-4 daun dipindahkan kedalam polybag ukuran $3 \mathrm{~kg}$ dengan komposisi media tanah kompos, pupuk NPK dan cocopeat dengan perbandingan 2:1:1. Setelah ditanam kedalam polybag, bibit tembakau dibiarkan dan disirami selama 7 hari sebagai proses aklimatisasi. Kemudian bibit tembakau secara terpisah dilakukan uji pemberian PQ dengan tipe gramoxone 276SL (Syngenta) dengan konsentrasi $(0.0005,0.001,0.0025$, dan $0.005 \%$ ), setiap konsentrasi dilakukan 3 kali ulangan. Setelah diberi perlakuan $\mathrm{PQ}$, bibit disinari dengan (40 watt $\mathrm{s}^{-} 2$ ) selama 1 jam , kemudian dari setiap perlakuan diambil sampel daun sebanyak 4 g untuk selanjutnya digunakan dalam uji malondialdehyde, kandungan asam askorbat (AsA), klorofil, dan kandungan air relatif.

\section{Penentuan kandungan Asam askorbat}

Kandungan asam askorbat ditentukan berdasarkan titrasi iodin. Daun tembakau dihaluskan hingga homogen. Ditimbang sebanyak 2 gram dimasukkan ke dalam gelas ukur $20 \mathrm{ml}$ dengan penambahan aquades sampai tanda $20 \mathrm{ml}$. Bahan selanjutnya disaring untuk memperoleh filtrat. Filtrat diambil sebanyak $5 \mathrm{ml}$ dengan pipet dan dimasukkan ke dalam Erlenmeyer $125 \mathrm{ml}$, lalu ditambahkan $2 \mathrm{ml}$ indikator amilum $1 \%$ dan aquades $20 \mathrm{ml}$. Larutan tersebut dititrasi dengan iodin 0,01 N sampai terjadi perubahan warna (biru keunguan). Perhitungan asam askorbat dengan standarisasi larutan iodin yaitu pada setiap $1 \mathrm{ml} 0,01 \mathrm{~N}$ iodin ekuivalen dengan $0,88 \mathrm{mg}$ asam askorbat [2].

\section{Statistik}

Penelitian dilakukan dengan menggunakan rancangan acak lengkap. Penelitian ini menggunakan 6 perlakuan (perlakuan dengan PQ 0.0005, 0.001, 0.0025, 0.005\%). Masing-masing perlakuan diulang sebanyak 4 kali Selanjutnya, data dianalisa menggunakan ANOVA one-way dan Least Significant Difference (LSD). P-values $<0.05$ dianggap signifikan.

\section{PEMBAHASAN}

\section{A. Kandungan Asam Askorbat}

Salah satu respon yang umum terjadi pada saat tanaman menghadapi cekaman biotik maupun abiotik adalah diakumulasinya antioksidan [20]. Jenis dan konsentrasi antioksidan yang diakumulasi juga bersifat species-dependent. Beberapa penelitian menunjukkan bahwa tanaman yang berada pada kondisi tercekam kekeringan mampu meningkatkan biosintesis antioksidan enzimatik dan non enzimatik [21]. Salah satu contoh antioksidan non enzimatik adalah asam askorbat (AsA). Pada penelitian ini, pengaruh pemberian paraquat terhadap kandungan AsA dilakukan pada hari ke-1 dan ke-28 setelah dicekam kekeringan.

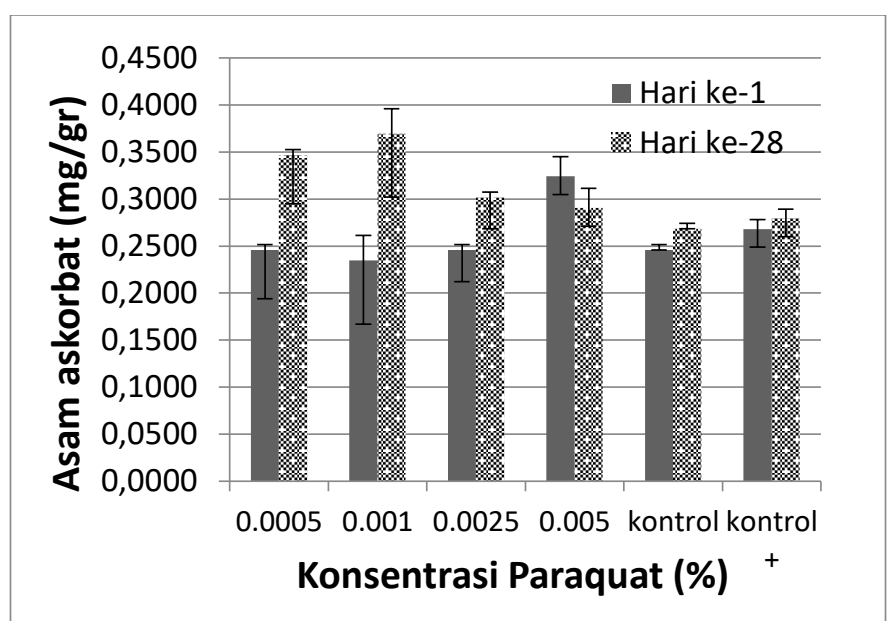

Gambar 1. Pengaruh pemberian pra-perlakuan paraquat dan cekaman kekeringan terhadap kandungan asam askorbat pada daun N. tabacum.

Kandungan AsA N.tabacum pada hari ke-1 pemberian cekaman kekeringan memiliki rata-rata sebesar $0.2608 \mathrm{mg} / \mathrm{gr}$, dengan kandungan AsA terendah berada pada $N$. tabacum yang diberi pra-paraquat dengan konsentrasi $0,001 \%$ sebesar $0.2347 \mathrm{mg} / \mathrm{gr}$, dan kandungan tertinggi berada pada $N$. tabacum yang diberi perlakuan paraquat dengan konsentrasi $0.005 \%$ sebesar $0.3241 \mathrm{mg} / \mathrm{gr}$. Sedangkan pada hari ke-28 setelah pemberian cekaman kekeringan, pemberian praperlakuan dengan paraquat tampak berpengaruh terhadap kandungan AsA (a <0.005). Rata-rata kandungan AsA di 
semua $N$. tabacum pada hari ke-28 mengalami peningkatan sebesar $0.0 .3094 \mathrm{mg} / \mathrm{gr}$. Pemberian pra-perlakuan paraquat pada hari ke 28 ini menunjukkan pengaruh signifikan terhadap kandungan AsA pada N. tabacum yang diberi paraquat dengan konsentrasi $0.001 \%$ jika dibandingkan dengan kontrol yaitu sebesar $0.3694 \mathrm{mg} / \mathrm{gr}(\mathrm{LSD}<0.005)$ (Gambar 1).

Paraquat merupakan senyawa organik yang pada umumnya digunakan sebagai salah satu komponen herbisida, yang bersifat polar yang masuk kedalam sel tumbuhan melalui mekanisme difusi pasif pada membrane sel, difusi pasif merupakan mekanisme masuknya molekul melewati membrane dengan menggunakan pergerakan gradient konsentrasi sehingga tidak memerlukan energy (Sterling, 1994). bertindak sebagai alternatif akseptor elektron yang mengambil elektron dari protein Fe-S pada fotosistem I. Selain itu, paraquat juga menghambat reduksi ferredoksin dan produksi NADPH. Selain itu, beberapa penelitian juga menyebutkan bahwa paraquat berfungsi sebagai senyawa organik yang mampu menginduksi terjadinya stres oksidatif karena mampu meningkatkan secara signifikan produksi ROS. Keberadaan ROS dapat memberikan dampak negatif bagi tanaman pada konsentrasi tinggi. Meskipun demikian, penelitian sebelumnya juga menunjukkan bahwa pada konsentrasi yang relative rendah, ROS dapat berfungsi sebagai second messenger [22], ROS yang lebih rendah sebagai molekul persinyalan dalam proses pertumbuhan dan perkembangan tanaman seperti pemanjangan sel [23], diferensiasi [24], morphogenesis, serta tanggapan terhadap berbagai rangsangan lingkungan, utamanya dalam meningkatkan kandungan senyawa AsA [25]. Diantara senyawa ROS yang mampu diinduksi oleh paraquat, hydrogen peroxide (H2O2) merupakan salah satu ROS yang diproduksi dalam konsentrasi yang relative lebih tinggi dibandigka ROS lainnya dan memiliki karakteristik berukuran molekul kecil sehingga memungkinkan untuk terjadinya difusi melalui membran sel dan terjadinya perpindahan dari kompartemen seluler yang satu ke kompartemen seluler lainnya untuk memfasilitasi proses signal transduksi [26].

AsA merupakan salah satu senyawa antioksidan paling kuat [2] yang berperan penting dalam mengatasi produk ROS [27] Biosintesis AsA terjadi di mitokondria melalui beberapa jalur,jalur utama yang paling jelas adalah SmirnoffWheelerjalur yang juga disebut jalur D-mannose / L-galaktosa [2]. Kemampuan asam askorbat dalam mengatasi ROS dapat dijelaskan pada siklus ascorbate-glutathione (Gambar 3).

Siklus glutathione-ascorbate adalah jalur metabolik yang berperan dalam mendetoksifikasi $\mathrm{H}_{2} \mathrm{O}_{2}$, yang dihasilkan sebagai produk samping sebuah proses metabolisme. Siklus ini melibatkan beberapa jenis antioksidan seperti AsA, glutathione, NADPH dan beberapa enzim lainnya (Noctor and Floyer,1998). Pada siklus ini, $\mathrm{H}_{2} \mathrm{O}_{2}$ akan direduksi menjadi air oleh askorbat peroksidase (APX) dengan menggunakan AsA sebagai donor electron (Gambar 3). Askorbat teroksidasi (monodehydroascorbate) kemudian diregenerasi oleh monodehydroascorbate reduktase (MDAR) [28]. Namun, monodehydroascorbate pada dasarnya adalah radikal dan jika tidak cepat direduksi, maka akan menjadi askorbat dan dehidroaskorbat. Dehidroaskorbat selanjutnya akan di reduksi menjadi askorbat oleh dehidroascorbat reduktase, menghasilkan glutathione teroksidasi (GSSG). Selanjutnya,
GSSG akan direduksi oleh glutathione reductase (GR) menggunakan NADPH sebagai donor elektron. Mekanisme inilah yang digunakan oleh tanaman dalam merespon adanya stress oksidatif. Namundemikian, adanya enzim antioksidan lainnya seperti peroksiredoxins dan glutathione peroxidases juga dilaporkan memiliki fungsi penting dalam mekanisme pertahanan tanaman terhadap cekaman kekeringan [29].

Pemberian pra perlakuan menggunakan paraquat dengan konsentrasi tertentu diperkirakan mampu meningkatkan kandungan AsA endogen pada $N$. tabacum sehingga mampu bertahan dalam menghadapi cekaman kekeringan. Hal ini juga serupa dengan penelitian yang dilakukan oleh [30] dan [31] yang menunjukkan bahwa peningkatan antioksidan dapat diinduksi dengan penggunaan inducer eksogen dan hal tersebut berpengaruh positif terhadap ketahanan tanaman terhadap cekaman kekeringan. Hal yang sama juga dilaporkan oleh [32] menunjukkan bahwa penyemprotan tanaman dengan $\mathrm{H}_{2} \mathrm{O}_{2}$ dapat meringankan stres kekeringan pada kedelai. Temuan tersebut menunjukkan bahwa $\mathrm{H}_{2} \mathrm{O}_{2}$ dapat memicu aktivasi mekanisme pertahanan seperti KAR, laju fotosintesis dan konduktansi stomata daun yang tertekan kekeringan termasuk peningkatan kadar antioksidan, yang membantu meringankan kerusakan dan memperbaiki pertumbuhan dan kinerja tanaman di bawah kekeringan.

\section{KESIMPULAN}

Pemberian pra-perlakuan menggunakan paraquat dengan konsentrasi $0.0005,0.001,0.0025$, dan $0.005 \%$ terbukti mampu meningkatkan kandungan senyawa antioksidan berupa asam askorbat pada kondisi tercekam kekeringan. Praperlakuan paraquat dengan konsentrasi $0.001 \%$ dinilai merupakan konsentrasi yang paling optimal sebagai second messenger untuk meningkatkan respon N. tabacum dibawah cekaman kekeringan.

\section{UCAPAN TERIMA KASIH}

Penulis M. Ichsan Al F. mengucapkan terima kasih kepada Bapak Dr. Nurul Jadid M.sc. selaku pembimbing dalam penelitian ini. Penulis juga berterima kasih kepada Ibu Noor Nailis Saadah, S.Si., M.Si. dan Ibu Wirdhatul Muslihatin, S.Si.,M.Si. sebagai penelaah penguji paper ini. Penelitian ini didanai oleh ITS 2017 .

\section{DAFTAR PUSTAKA}

[1] Z. E. Taiz L, Plant Physiology. California: The Benjamin/Cummings Publishing Company, Inc, 1991.

[2] F. Aysin, F., Bensan,.E., Elif., Eyidogan, "Generating salt-tolerant Nicotiana tabacum and identification of stress-responsive mRNAs in transgenics," Turk. J. Botany, vol. 39, pp. 757-768, 2015.

[3] A. Abiri, R., Noor, A., Mahmood, M., Zetty, Norhana, Y., Narges, A., Mahmod, S., Alireza, V., Nahid, K., Parisa, "Role of ethylene and the APETALA 2/ethylene response factor superfamily in rice under various abiotic and biotic stress conditions Rambod Abiri," Environ. Exp. Bot., vol. 134, pp. 33-44, 2017.

[4] M. Rachmat, "Pengembangan ekonomi tembakau nasional:kebijakan Negara maju dan pembelajaran bagi Indonesia," Anal. Kebijak. Pertan., vol. 8, no. 1, pp. 67-83, 2010.

[5] H. Darvishzadeh , R., Mirzaei, L., Maleki, H., Lauretin, "Genetic variation in oriental tobacco (Nicotiana tabacum L.) by agromorphological traits and simple sequence repeat markers," Rev. 
Ciência Agronômica, vol. 44, no. 2, pp. 347-355, 2013.

[6] J. Denduangboripant, "Genetic Polymorphism between Tobacco Cultivar-groups Revealed by Amplified Fragment Length Polymorphism Analysis," J. Agric. Sci., vol. 2, no. 2, 2010.

[7] D. Ru, Q., Li-juang, W., Li, W., Wang, J., Yu-ting, "In Vitro Antioxidant Properties of Flavonoids and Polysaccharides Extract from Tobacco (Nicotiana tabacum L.) Leaves. Molecules," MDPI, vol. 17, pp. 11281-11291, 2012

[8] C. Martinez, N., Pedro, A., Joaquin, A., Antonia, P., Antonio, C., Ruben, B, Juan, "Optimization of non-catalytic transesterification of tobacco (Nicotiana tabacum) seed oil using supercritical methanol to biodiesel production," Energy Convers. Manag., vol. 131, pp. 99108, 2017.

[9] G. Davalieva, K., Maleva, I., Filiposki, K.Spiroski, O., Efremov, "Genetic Variability of Macedonian Tobacco Varieties Determined by Microsatellite Marker Analysis. Diversity,” vol. 2, pp. 439-449, 2010.

[10] J. Shuai,.C., Guan-shan, L., Wang, Y., Sun, Y., Chen, "Cloning of a Calcium-Dependent Protein Kinase Gene NtCDPK12, and Its Induced Expression by High-Salt and Drought in Nicotiana tabacum," Agric. Sci. China, vol. 10, pp. 1851-1860, 2011.

[11] L. Yue, Y., Mingcai, Z., Jiachang, Z., Liusgheng, D., Zhaohu, "Arabidopsis LOS5/ABA3 overexpression in transgenic tobacco (Nicotiana tabacum cv. Xanthi-nc) results in enhanced drought tolerance," Plant Sci., vol. 181, pp. 405-411, 2011.

[12] N. S. dan Y. B. Ai, "Konsentrasi klorofil daun sebagai indikator kekurangan air pada tanaman," J. Ilm. Sains, vol. 11, pp. 166 - 171, 2011.

[13] C. Sun, J.Jing, G., Jun, Z., Shuang, H., Aiping, S., Fadi, C., Weimin, F., Jiafu, J., Sumei, "Changes in leaf morphology, antioxidant activity and photosynthesis capacity in two different droughttolerant cultivars of chrysanthemum during and after water stress," Sci. Hortic. (Amsterdam)., vol. 161, pp. 249-258, 2013.

[14] V. Esmaeilpour, A., Marie, C., Roeland, S., Pascal, B., Patrick, "Variation in biochemical characteristics, water status, stomata features, leaf carbon isotope composition and its relationship to water use efficiency in pistachio (Pistacia vera L.) cultivars under drought stress condition," Sci. Hortic. (Amsterdam)., vol. 211, pp. 158-166, 2016.

[15] J. Hysková , V., Miedzinska., Dobra, "Phosphoenolpyruvate carboxylase, NADP-malic enzyme, and pyruvate, phosphate dikinase are involved in the acclimation of Nicotiana tabacum L. to drought stress," J. Plant Physiol., vol. 171, pp. 19-25, 2014.

[16] B. Nxele, X., Klein, A., Ndimba, "Drought and salinity stress alters ROS accumulation, water retention, and osmolyte content in sorghum plants," South African J. Bot., vol. 108, pp. 261-266, 2017. water deficit stress: oxidative stress and defence mechanisms," Physiol Plant, vol. 93, pp. 25-30, 1995.

[18] X. Liu, Z., Zhang, "Exogenous paraquat changes antioxidant enzyme activities and lipid peroxidation in drought-stressed cucumber leaves," Sci. Hortic. (Amsterdam)., vol. 121, pp. 138-143, 2009.

[19] Q. Lascano, R., Nacira, M., German, R., Marianela, R., Mariana, M., Victorio, T., Gaston, Herbicides - Properties, Synthesis and Control of Weeds. china: Intech open science, 2012.

[20] F. Anwar, L. Said, and M. Gilani., "Moringa oleifera a Food Plant with Multiple Medicinal Uses," Phyther. Res., vol. 21, pp. 17-25, 2017.

[21] N. S. B.N. Devendra, P. Talluri, "Callus Induction and Somatic Embryogenesis of Moringa oleifera Lam an anti-radiation Plant," $J$. Agric. Technol., vol. 8, pp. 1953-1963.

[22] D. F. Wetherell, Plant Tissue Culture Series. New Jersey: Avery Publishing Group Inc, 2008.

[23] S. C. V. M.A.J. Toonen, "Initiation of Somatic Embryos from Single Cell. In: Wang, T.L., A. Curming (ed). Embryogenesis the Generation of Plant," Sci. Publ. Ltd., pp. 173 - 177, 1996.

[24] Y. O. T. M. Lambardi, C. Benelli, E.A. Ozudogru, "Synthetic Seed Technology in Ornamental Plants," Floric. Ornam. Plant Biotechnol., vol. 2, 2006.

[25] V. K. K.M.B. Arun, V. Vakeswaran., "Enchancement of Synthetic Seed conversion to sedling in hybrid rice," Plant Cell Tiss Org Cult, 2005.

[26] G. . W. L. Roostika, R. Purnamaningsih, Supriati, I. Mariska, N. Kumaida, "Pembentukan Benih Sintetik Tanaman Nenas," J.Hort, vol. 22, no. 4, pp. 316-326, 2012.

[27] R. Mutia, "Efek Antibakteri Minyak Atsiri Kayu Manis terhadap Enterococcus faecalis sebagai bahan Medikamen Saluran Akar secara In Vitro," USU, 2010.

[28] C. E. S. W. Muslikhatin, N. Jadid, I.D. Puspitasari, "Growth of Vegetative Explant Moringa oleifera on Different Composition of Auxin and Cytokinin and its Synthetic Seed Germination," in Proceeding of International Biology Confeence, 2016.

[29] R. L. Pierik, In Vitro Culture of Higher Plant. London: Kluwer Academic Publisher, 1987.

[30] R. F. Oetami, Kombinasi embriogenesis langsung dan tak langsung pada perbanyakan kopi robusta. Jember: Pusat Penelitian Kopi dan Kakao Indonesia, 2015.

[31] P. M.C. Renddy, K.S.R. Murthy, "Synthetic Seed: A review in agriculture and foresty," Biotechnology, vol. 11, pp. 1254 - 14275, 2012.

[32] S. I. Warnita, "Pertumbuhan dan Ketahanan bibit mikro kentang (Solanum tuberosum L.) enkapsulasi pada beberapa konsentrasi alginat," pp. 139-143, 2008. 